\title{
The Power of Fantasy to Create New Reality
}

\author{
Hyun Sook Oh \\ Department of Korean Language and Literature, Chungbuk National University, Cheongju, Korea \\ 새로운 리얼리티를 창조하는 환상의 힘 \\ 오현숙 \\ 충북대학교 국어국문학과 \\ Book title: Wijeodeu beikeori [Wizard bakery] \\ Book title: Singkeo [Syncher] \\ Author/Year: Byung Mo Gu, 2009 \\ Author/Year: Mi Joo Bae, 2010 \\ Publisher: Changbi, Seoul, Korea \\ Publisher: Changbi, Seoul, Korea \\ Size: 148 * $210 \mathrm{~mm}, 224$ pages \\ Size: 148 * $210 * 20 \mathrm{~mm} / 295 \mathrm{~g}, 224$ pages \\ ISBN: $9788936456160(8936456164)$ \\ ISBN: $9788936456290(8936456296)$
}

Book title: Yaktari sijakdwaetda [Robbery began]

Author/Year: In Seok Choi, 2010

Publisher: Changbi, Seoul, Korea

• 위저드 베이커리, 구병모, 2009

Size: 153 * 224 * $20 \mathrm{~mm} / 338 \mathrm{~g}, 252$ pages

- 약탈이 시작됐다, 최인석, 2010

ISBN: $9788936456283(8936456288)$

• 싱커, 배미주, 2010

This review focuses on how the formation of a new reality through the interaction of fantasy and reality in young adult literature was explored since the 2000s. Byung-mo Gu, who depicts the growth process of youth through the magical fantasy of a subculture, In-Suk Choi, who reconstructs the grammar of youth's desire and growth through love beyond the taboo and explores plural reality and its ethics through virtual reality; and Mi-joo Bae all present a common problem setting by exploring the possibility of fantasy interacting positively with reality. In the literary works of the above writers, fantasy interacts effectively with the dominant reality and expands the possibility of a positive manifestation of the reality and position of youth.

Keywords: young adult literature, fantasy, reality, subculture, desire, virtual reality

\section{닫힌 일상을 넘어서}

현재 우리 사회의 청소년은 온갖 사회적 모순의 무게를 온몸
으로 견뎌내는 존재다. 그들이 노동과 사회참여를 통해 온전 한 성인으로 인정받는 시기는 후기 자본주의의 논리에 의해 서 끊임없이 유예되고 있다. 청소년들은 삶의 중요한 가치들
Corresponding Author: Hyun Sook Oh, Children's literature researcher/ Department of Korean Language and Literature, Chungbuk National University, Cheongju, Korea

E-mail: 0405mars@naver.com
(c)The Korean Association of Child Studies

This is an Open Access article distributed under the terms of the Creative Commons Attribution Non-Commercial License (http:// creativecommons.org/licenses/by-nc/4.0) which permits unrestricted noncommercial use, distribution, and reproduction in any medium, provided the original work is properly cited. 
이 끊임없이 미래로 지연된 채 반복적 일상 안에 갇혀있다. 이 러한 청소년의 현실을 반영하는 청소년 문학 역시 학교와 집 을 중심으로 왕따, 낙태, 입시문제, 가정 폭력 등의 닫힌 일상 을 중점적으로 형상화하고 있다.

따라서 청소년 문학이 어떻게 닫힌 일상을 넘어서는 힘을 형상화할 수 있을 것인가는 매우 중요한 문제이다. 2000년대 중반 이후 환상문학이 유년기 동화와 청소년 문학에서 그 양 적, 질적 팽창을 보이고 있는 것은 결코 우연이 아니다. 환상성 을 중요한 작품의 자질로 생각하는 그림책이나 동화와 달리, 청소년 문학에서는 전통적으로 사실주의 문학과 교훈주의 문 학이 주류적 흐름을 차지해 왔다. 그런데 2000년대 이후 청소 년 문학에서 환상과 현실의 상호작용을 통해 형성되는 새로운 리얼리티를 탐색하는 흐름이 두드러지고 있다. 위기철, 채인 선을 잇는 황선미, 박상률, 공지희, 고재은 등의 동화 작가군이 선도했던 환상문학은 최근에 구병모, 배미주, 최민경과 같은 신진 청소년 문학 작가의 발굴과 듀나, 최인석과 같은 기성의 중견 작가군의 참여로 새로운 흐름을 만들어 내고 있다.

성인 문학에서 나타나는 현실과 분리된 환상과 달리, 청소 년 문학에서 환상은 새로운 리얼리티를 구성하는 중요한 토대 를 이룬다. 최근의 청소년 문학의 환상은 닫힌 일상의 리얼리 티를 넘어서는 새로운 리얼리티에 대한 탐색으로 나아가는 계 기로 작용한다는 점에서 의미가 크다. 기존의 청소년 문학은 전통적으로 리얼리티의 재현이라는 관점에서 주로 논의되어 왔다. 그러나 기실 현실과 묘사된 대상이 동일성을 지닌다는 과거의 재현 개념으로는, 왜소화된 존재로 닫힌 일상을 살아 가는 청소년들의 삶을 폐쇄적 순환으로 형상화하는 한계를 넘 어 서기 어렵기에 청소년 문학에서 환상의 대두는 더욱 중요 한 현상이다.

이 글은 관습화된 리얼리티, 단일한 리얼리티가 지닌 한계 를 극복하면서, 세계와 대면하는 새로운 리얼리티를 만들어내 는 '환상의 힘'에 주목하고자 한다. 환상이 현실과 적극적으로 상호작용하면서 새로운 리얼리티를 복원하는 양상과 그것이 지니는 의미를 살펴보는 것, 이를 통해 청소년 문학의 다른 가 능성을 의미화하는 것이 이 글의 목적이다.

\section{하위문화와 환상: 구병모의 경우}

청소년 문학에서 작가와 독자의 관계는 '비대칭적'이라는 점 이 특징적이다. 성인 작가와 청소년 독자의 인지 역량, 인생 경 험, 언어적 표현 수준은 서로 다르다. 성인 문학과는 다른 작가
와 독자의 독특한 의사소통구조는 청소년과 성인 사이의 불 균형성, 불균등성, 비대칭성의 문제를 제기한다.(Nikolajeva, 2005/2009; Wall, 1991) 종종 일부 작가들이 '청소년을 위한 문 학'을 내세우며 청소년을 배려하는 것처럼 보이지만, 그 심층 에는 청소년들에게 그 사회의 주류 이데올로기를 전파하고자 하는 정치적 무의식이 놓여져 있는 것은(Jung, 2008) 이러한 구조적 특징을 인식하지 못했기 때문이다.

따라서‘청소년은 어떤 방식으로 자신의 이야기를 쓸 수 있 는가?' 라는 문제가 최근 비평에서도 중요한 쟁점으로 부각되 고 있다(Jung, 2010; Ko, 2009; Oh, 2009). 청소년이 직접 창작 의 주체로 나서야 한다는 일부 주장은 명쾌한 해결책처럼 보 이지만, 이는 근본적인 해결방법이 아니다. 청소년이 창작 주 체가 되는 것은 교육학적으로 상당히 중요한 의미를 지닌다. 그러나 단순히 이러한 방법으로 작가와 독자 간의 의사소통의 ‘비대칭성’이라는 간극이 쉽게 해결될 수는 없다. 청소년과 성 인은 다른 참조 틀을 지녔다. 각기 고유한 지식수준, 경험, 문 화적 배경 등을 지니고 있다. 만일 청소년 작가가 성인 작가와 동인한 능력을 획득하더라도, 그 순간 대다수 침묵하는 청소 년들의 입장을 대변하기 어렵다는 딜레마에 빠진다. 청소년 을 대상화하지 않고 "당당한 주체로 인정하고 접근하려는 것 이 청소년 문학의 본질적인 부분”(Oh, 2009, p. 175)이라는 지 적은 타당하다. 하지만 보다 중요한 것은 '어떻게' 청소년을 당 당한 주체로 '재현'할 수 있는가 하는 방법의 문제이다. 이러한 문맥에서 '재현'은 여전히 중요한 문제이다.

최근에 청소년을 기존의 아동이나 성인과 다른 독자적인 문화를 지닌 존재로 형상화한 작품들이 등장하였다. 신여랑의 몽구스 크루, 배유안의 스프링벅, 김려령의 완득이 등은 공통 적으로 청소년들의 하위문화를 차용한 작품들이다. 이들은 비 보이의 춤과 킥복싱 등의 하위문화를 통해서 남과 다른 개체 의 특이성, 나아가 청소년 집단의 특이성을 보여준다. 하지만 신여랑이 비보이로 상징되는 하위문화를 통해 '나는 남과 다 르다'는 다소 폐쇄적인 구별짓기에 머문 것이나, 배유안이 비 보이로 상징되는 하위문화를 차용하면서도, 자유, 정의 등의 규범적 가치를 지향하는 착한 청소년 상에 의해 현실의 갈등 을 쉽게 해소시킨 점은 한계로 남는다. 하위문화는 단순한 구 별짓기 전략이나 소재적 차용을 넘어서 지배문화로부터 배제 된 불온성을 복원할 때 진정한 힘을 드러낼 수 있기 때문이다. 이러한 문제의식 속에서 구병모의 위저드베이커리는 왜소한 십대의 현실을 하위문화에 뿌리를 둔 환상을 통해서 대상화하 지 않고 재현하고 있다는 점에서 주목된다.

이 작품은 집-모험-집이라는 전통적인 이야기의 기본 플롯 
을 따른다. 전통적 민담에서는 영웅적 인물이 모험을 통해서 더 성숙한 이후 집으로 귀환한다. 그러나 이 작품의 주인공인 '나'가 속한 현실의 집은 온갖 비극이 집약된 공간이다. 아버지 의 아동성추행, 엄마의 자식유기와 자살, 계모의 학대가 자행 된다. 따라서 이 작품은 전통적인 집-모험-집의 플롯을 따르면 서도, 인간을 완전하게 보호해주었던 집으로부터 추방된 왜소 한 인물의 모험과 귀환이라는 문제를 담고 있다.

주인공인 '나'는 자신을 둘러싼 현실을 적절히 구조화하거 나 표현하지 못한다. "이유를 안다고 해서 상황이 달라질 일도 아니고, 남은 거라곤 원인이나 치유에의 희망이 아니라 피투 된 현상뿐. 그저 혓바닥과 입천장의 불필요한 마찰을 통제할 수 없는 현상. 점점 말하기를 피하는 나. 점점 말을 잃어가는 나.”(Gu, 2009, p. 40) '나'의 말더듬이 습관은 언어를 매개로 자 신의 현실을 온전히 구조화할 수 없는 나약한 위치를 상징한 다. 주인공은 현실에서는 자신을 둘러싼 모순을 인식하고 발 화할 수 있는 능력을 지니지 못한 것이다.

그러나 '나'는 폭력적인 현실에서의 엄마의 자궁(집)에서 벗어나 마술적 자궁(마법사의 오븐) 속으로 들어감으로써 비 로소 현실에 맞설 수 있는 내면의 모험을 시작한다. 이는 단순 히 마술적 세계로의 퇴행을 의미하지 않는다. 오히려 마술적 힘에 의해 '나'는 온전한 의사소통을 할 수 있는 주체가 된다. 마법적 세계에서는 완성되지 않은 문장도 온전한 의미로 전 달되며 심지어 침묵에 의해 발화되지 않은 의미도 상대에게 전달될 수 있다. 환상적인 힘을 통해서, 주인공은 우리가 소위 '현실'이라고 부르는 기존 질서에서 불가능한 영웅적 힘을 얻 는다.

마법사가 운영하는 빵가게는 부두인형, 미신과 주술의 힘 이 있는 쿠키 등 비이성적인 민중신앙에 기반한 환상으로 가 득찬 공간이다. 근대사회에서 이러한 민중신앙은 합리성에 반 하는 미신으로 간주되어 주류적인 지배문화에서 추방되었지 만, 민중들의 하위문화 안에서는 여전히 전승되고 있다. 작가 는 민중들의 하위문화에 뿌리를 둔 전통적 환상의 힘을 위저 드 베이커리라는 공간을 통해서 복원한다. 전통 사회의 리얼 리티는 현대 사회의 리얼리티와 전적으로 다르다. 우리는 일 상적이고 사소한 사실들을 실제적인 것으로 받아들이지만, 민 중신앙에 근간한 전통사회에서는 환상과 현실이 통합된 것을 리얼리티로 받아들였다. 작가는 민중들의 하위문화에 기반한 전통적 환상을 리얼리티를 구성하는 힘이라는 현대적 의미로 재해석 한다.

이러한 리얼리티 개념은 환상이 적극적으로 리얼리티를 구 성하는 동화나, 현실의 한계를 넘어서고자 하는 오늘날 청소
년 문학에 매우 효과적이다. 작가가 복원하고자 하는 환상은 현실과 분리된 것이 아니라 현실에 적극적으로 개입하면서 리 얼리티를 재구성하는 요소이다. 위저드 베이커리의 물건들은 주술적인 힘으로 자신보다 우수한 성적을 가진 친구를 저주하 거나, 사랑의 감정을 불러일으키면서 현실을 재구성한다. 하 지만 작가는 마법적 도구를 얻었다고 전형적인 장르물의 서사 에서처럼 모든 현실의 문제가 해결되지는 않도록 한다. 마법 의 힘에 의해 변화된 물질계의 균형을 맞추어야하는 '우주론' 을 통해서 이를 확인할 수 있다. 지나치게 뒤틀어진 물질계와 비물질계 사이의 균형을 유지하는 것의 중요성을 강조하는 것 은, 작가가 환상과 현실이 균형잡힌 리얼리티를 이루는 세계 를 지향하고 있음을 반증한다.

'나'는 마술적 공간인 위저드 베이커리의 점원으로 일하면 서, 그리고 자신의 의지로 점장을 몽마의 습격으로부터 구하 면서 스스로의 존재를 책임질 수 있는 힘을 얻는다. 다시 현실 의 집으로 되돌아가는 '나'에게 점장은 시간을 되돌릴 수 있는 '머랭쿠키'를 선물한다. 하지만 마법적 선물은 단순한 소원성 취의 도구가 아니다. 이는 Y와 $\mathrm{N}$ 의 선택의 문제를 통해 '나'의 현실에 개입하며, 따라서 주인공이 감당해야하는 삶의 무게와 균형을 이루면서 마법적 힘이 현실을 구성하기 때문에, 머랭 쿠키를 사용했을 때와 사용하지 않았을 때 현실의 낙차는 크 지 않다. Y의 경우, 나는 마법의 힘으로 과거로 되돌아가서 아 빠의 재혼에 대해서 “아니, 나는 싫어요.”라고 분명하게 발화 할 수 있게 된다. 마법의 힘뿐만 아니라, 자신의 현실을 감당하 고자하는 내적 의지가 바탕이 되기 때문이다. N의 경우, 가족 의 모든 상처를 그대로 체험으로 받아들이면서 "조금씩, 아주 조금씩 티가 나지 않을 정도였지만, 음절이 어절이 되고 어절 이 구를 이루는 것을 한 해 한 해" $(\mathrm{Gu}, 2009$, p. 242) 깨닫게 된 다. 몇 년 후 말더듬을 극복하고 일상을 살아가는 '나'에게 여 전히 위저드 베이커리의 마술적 존재는 일상의 일부로 잠재되 어 있다. 이와 같이 위저드 베이커리는 민중신앙에 근간한 전 통사회의 리얼리티 개념을 복원하면서, 동시에 오늘날 환상과 현실이 적절한 조화를 이루는 새로운 리얼리티를 제시하고 있 다.

머릿속에서 이성의 목소리가 내게 말을 건넨다. 추억은 그대로 상자 속에 박제된 채 남겨두는 편이 좋아 (중략) 그 러나 나는 그 목소리를 무시하고 더욱 빨리 달린다. 추억 이라니. 환상이라니. 그 모든 것은 내게 있어서는 줄곧 현 재였으며 현실이었다. 마법이라는 것 또한 언제나 선택의 문제였을 뿐 꿈속의 망중한이 아니었다(Gu, 2009, p. 248). 
일반적으로 청소년은 환상이 분리되지 않은 동화의 세계에 서 벗어나 이성과 객관성이 지배하는 리얼리티의 세계로 진입 해야 진짜 성장을 한 것으로 간주된다. 그러나 구병모는 이러 한 지배적인 성장 법칙을 거부한다. 반대로 그는 환상이 적극 적으로 현실에 개입하면서 가치의 세계를 복원하는 주술적 마 법이 오늘날 청소년의 성숙에 필요함을 강조한다. 그리고 이 를 매개하는 추동력으로 독특한 청소년들만의 하위문화가 작 동하고 있다. 최근 청소년 문학에서 빈번하게 형상화되는 하 위문화는 단순한 구별짓기 전략이나 대중문화적 취향을 나타 내는 소재에 머무르는 한계를 보이기도 한다. 하위문화는 기 성세대의 지배문화에 의해 억압된 청소년의 내적 성숙을 적극 적으로 매개하는 역할로 기능할 수 있다. 이때 비로소 지배적 인 성장의 경로에서 벗어나 그들만의 능동적인 성장의 가능성 을 풍부하게 보여줄 수 있는 청소년 문학이 가능할 것이다. 이 점에 하위문화와 환상이 결합되는 구병모의 작품이 지니는 의 미가 있다.

\section{금지된 욕망을 넘어: 최인석의 경우}

청소년기에 인격을 형성하는데 있어서 이성과 감정은 중요한 두 축이다. 그러나 기존의 청소년 문학에서는 청소년이 이성 적 사고를 통해서 합리적 세계로 진입하는 측면만이 비대하게 강조되었다. 반면에 감정에 사로잡힌 청소년이 정념이나 욕망 의 세계로 진입하는 것은 상당히 위험한 것으로 이해되었다. 스스로 제어하지 못하는 사랑과 욕망에 휘둘리는 청소년은 작 품 안에서 그 자체로 문제아나 위험한 존재로 간주되어왔다.

그동안 억압되었던 감정의 영역에 대한 탐구가 충분히 이 루어져야 청소년 문학에서 성장의 의미가 온전히 형상화 될 수 있다. 성장소설은 청소년 문학에서 중요한 위치를 차지한 다. 김중미의 괭이부리말 아이들, 김해원의 열일곱살의 털, 김 려령의 완득이 등의 작품에서 우리는 무섭게 성장하는 아이 들과 청소년의 빼어난 생명력을 만날 수 있다. 하지만 청소년 의 성장을 사실적으로 묘사하는 작품들에서 이들의 성장이 공 통적으로 헌신적인 조력자들의 외부적 힘에 크게 기댈 수밖에 없는 이유는 무엇인가? 물론 성인 조력자의 역할이 부정적인 것만은 아니다. 이들의 도움으로 청소년들을 합리적 질서나 규칙들에 편입되도록 함으로써 강력한 행동의 변화를 이끈다.

그러나 객관성과 관찰에 큰 가치를 부여하는 기존의 리얼 리티 개념으로는 이성 중심의 강력한 자장으로부터 벗어나 새 로운 리얼리티를 스스로 탐색하는 청소년의 내적 성장을 드러
내는 데는 어려움이 따른다. 이제는 청소년 성장의 핵심적인 한 축을 이루고 있으나, 배제되었던 감정과 욕망의 내적 성장 과정이 우리 문학에서 충분히 조명될 필요가 있다. 이런 의미 에서 김해원의 작품은 중요한 시작점이다. 성장하는 '털'로 상 징되는 청소년의 욕망과 이를 관리하고자 하는 학교의 규율 권력 간의 갈등을 전면에 내세운 작품이기 때문이다. 하지만 이 작품에서 욕망의 문제는 깊이있게 형상화되지 못하고 “시 민적 권리확보 차원의 메시지로 소진” (Won, 2009, p. 220)되 었다는 점에서 한계를 지닌다반면에 최인석의 약탈이 시작됐 다는 '꿈'의 형식을 매개로 현현하는 청소년의 금지된 사랑과 욕망에 대해 탐구한다. 이 작품은 청소년의 욕망뿐만 아니라 합법과 불법의 기준을 만들어내는 사회 시스템 자체를 사유하 면서 성장하는 청소년을 그려내고 있다는 점에서 의미가 있 다.

성준은 담임선생의 심부름으로 무단결석한 반 친구 용태네 집에 찾아갔다가 친구 어머니에게 매혹된다. 현실에서 그녀는 친구의 어머니이자, 술집 ‘평양주점'의 마담이다. 그러나 성준 의 꿈속에서 그녀는 여러 얼굴로 나타난다.

그녀를 생각할 때마다 성준은 혼란스러웠다. 그녀는 용태 어머니인가 장 마담인가? 아니면 그와 꿈속에서 만나기만 하면 과감하게 섹스로 돌입하는 그의 연인인가? 그에게 그녀는 이 세 얼굴을 모두 지니고 있었다. 그 세 얼굴은 부 분적으로 겹치고 분리되었다(Choi, 2010, p. 65).

동물적인 성적 욕망의 대상이자 연인으로서의 사랑을 넘나 드는 그녀의 존재는 정상과 비정상의 기준 사이에서 요동친 다. 성준은 그녀에게 현실의 용태 어머니도 아닌, 술꾼들의 장 마담도 아닌, 자신만의 연인으로서 '미즈 장'이라는 호칭을 붙 여준다. 미스도 미시즈도 아닌 '미즈 장'. 현실에서 그녀는 단 일한 실재이지만, 성준에게 그녀는 '세 얼굴'을 지닌 존재이다. 그녀는 학교 친구인 용태의 어머니이자, 만인의 연인인 장마 담이며, 오직 나만의 연인인 ‘미즈 장'이다.

이 작품에서 '꿈’이라는 환상은 현실에서 억압된 사랑을 다 시 현실로 소환하는 장치다. '꿈'에 의해 다시 현실로 소환된 사랑은 성준의 내면 안에서 '잠재적 리얼리티'를 만들어 낸다. 성준은 금지된 욕망이 '꿈'을 통해서 외부로 표출되자, '자신의 사랑이 현실에서 실현될 수 있는가? 이 사랑은 올바른 것인가 그른 것인가? 그것을 결정하는 기준 자체는 올바른 것인가?' 등을 스스로 질문한다. '잠재적 리얼리티'는 현실에서 실현될 수도 있고, 실현되지 않을 수도 있다. 작품에서 성준의 순수한 
사랑의 열망은 현실의 냉혹한 논리 앞에 처참히 무너지는 것 으로 귀결된다. 무너진 사랑 앞에서 현실의 무게를 감당해야 하는 것은 온전히 성준의 몫이다. 하지만 현실에서 실현되지 못한 성준의 '미즈 장'과의 사랑은 완전히 좌절된 것이 아니다. ‘밤의 망명지' 혹은 ‘약탈 지역'처럼 현실세계에서 추방된 곳에 그들의 사랑은 '또 다른 잠재적 리얼리티'로 존재한다. 언제든 지 또 다른 현실로 존재하는 '미즈 장'과의 사랑은 현실의 경계 로 넘어올 수 있으며, 작품의 결말은 그 가능성을 열어 놓는다.

이처럼 최인석의 약탈이 시작됐다는 기존의 청소년 소설 이 미지의 영역으로 남겨두었던 청소년의 욕망의 분출, 금기 의 위반과 이를 통한 내적 성장을 매우 밀도 형상화한다. 작가 는 주인공 성준으로 하여금 현실을 지배하는 규칙들을 넘나들 면서 실현된 리얼리티와 잠재된 리얼리티를 동시에 지닌 복합 적인 내면 성장을 이끌어 낸다. 이것은 이전의 성장소설에서 찾아보기 어려운 분명한 성과이다. 이러한 성장 안에는 사랑 을 규정하는 표준적 해석이나 자동적 가치부여로부터 벗어날 수 있는 잠재적 힘을 충분히 가질 수 있게 하기 때문이다. 나아 가 이 작품은 성(性)과 사랑에 대해 청소년에게 강요하는 규칙 이 성인의 기준에 의해 폭력적으로 작동한다는 것을 보여 줌 으로써 전복적 내러티브의 효과를 생성한다. 기존에 청소년의 사랑을 다룬 작품은 주로 낙태와 미혼모처럼 비정상으로 구획 된 현실논리에 의한 비극적 결말을 맞는 희생양으로서의 청소 년을 다루었다. 하지만 최인석은 청소년이 대상화된 존재가 아니라 스스로 내적 성장을 이르는 과정을 뛰어나게 그려내고 있다. 이는 그가 성인의 기준에 의해 금지된 청소년들의 억압 된 욕망을 환상을 통해 복권시키는 것에 기인한다. 이제 우리 청소년 문학에는 새로운 성장의 문법이 필요하다. 그것은 대 상화된 규범의 성장이 아닌, 청소년 고유의 자연스러운 욕망 을 승인하는 것으로부터 모색될 수 있을 것이다. 최인석의 작 품은 성인의 관념과 청소년의 현실 사이의 괴리로서 존재하는 '성장'의 문제를 환상을 통해 정면에서 제기하고 있다는 점에 서 그 의미를 지닌다.

\section{리얼리티의 확장과 그 윤리 : 배미주의 경우}

과학 기술은 단지 리얼리티를 인식하는 수단이 아니라 인식 주체가 대면하는 리얼리티 자체를 확장한다. 과학의 진보는 관찰이 가능한 세계를 청각적, 시각적 현상들뿐만 아니라 화 학적, 생물학적 현상들로 확장시켰다. 현미경은 인간이 지각
하기에 너무 크거나 작은 대상을 가시적 대상으로 전환하며, 뇌파 영상 기술은 그 자체로 시각적이지도 청각적이지도 않 은, 그 너머에 있는 실체들을 인식할 수 있도록 만든다. 특히 컴퓨터와 핸드폰을 자신의 연장(延長)된 신체처럼 자유롭게 다루는 청소년들에게 과학기술은 새로운 재현의 수단이다. 재 (re)-현(présentation)되는 것은 말 그대로 다시 나타나는 것이 다. 고전적인 재현 개념은 단 하나의 리얼리티만을 가치 있는 것으로 여겼다. 그러나 오늘날의 과학은 객관세계의 실증적인 측면을 그대로 반영하는 수단이 아니라 우리에게 지각되지 않 은 리얼리티를 생성하고 파악하는 기제로 확장되고 있다. 이 는 특히 가상현실의 대두에서 두드러진다.

과학 기술의 발달과 함께 등장한 과학적 환상 소설은 인간 의 물리적 한계를 넘어서 복수(複數)의 리얼리티를 재현한다 는 점에서 중요하다. 과학적 환상 소설에서 하나의 현실은 미 립자들이 소용돌이치는 물리학적 세계로, DNA의 조합과 변 주에 의해서 지배되는 세계로, 0 과 1 의 2 진법에 의한 전자적 흐름으로 각기 상이한 여러 겹의 리얼리티‘들’로 변주된다. 가 상현실의 재현에서 중요한 것은 실재 개념을 아예 포기하는 것에 있는 것이 아니라 현실을 복수화하는데 있다. 즉 실재의 개념을 포기하고 하는데 요점이 있는 것이 아니라 현실을 구 성하는 수많은 리얼리티들로 복원하고, 그것들 각각의 상이한 맥락들을 세심하게 밝혀 주는 데 핵심이 있다.

최근에 가상현실을 다룬 대부분의 작품에서 가상현실은 현 실과 동떨어진 인공적인 세계로 그려지거나, 왕따와 학원폭 력과 같은 현실의 문제로부터 잠시 벗어날 수 있는 도피적 공 간으로 그려진다. 이들 작품에서 나타나는 가상현실은 실재를 대체하는 인공적인 우주와 게임 세계의 소재적 새로움에도 불 구하고, 결과적으로 환상을 현실의 대척점에 있는 것 또는 현 실을 대체하는 가짜로 사고한다는 점에서 기존 관점과 크게 다르지 않다. 이에 반해 배미주의 싱커는 가상현실을 통해서 확장된 현실들을 다채롭게 그리며 다시 현실과 상호작용하는 역동적 관계의 양상을 보여준다는 점에서 중요한 작품이다.

싱커(Bae, 2010)의 거대 지하 도시 '시안'과 열대우림을 그 대로 재현한 '신아마존'이라는 인공적 세계는 우리에게 새로 운 경험을 제공한다. '시안'은 자연을 추방한 인공, 가짜의 세 계다. 주인공 미마는 성적 향상을 위해 복제약품을 사러 갔다 가 '신아마존'을 체험할 수 있는 버추얼 게임 '싱커'를 얻게 된 다. 게임 '싱커'는 진짜 세계를 모방한 '신아마존'을 다시 복제 한 그림자에 대한 그림자이다. 하지만 '싱커'는 가상현실을 넘 어서 진짜의 세계로 안내한다. 
"게임?"

“그래. 이름은 ‘싱커'(Syncher). 동조자란 뜻이야.”

"가상 체험 게임이라면 전에도......"

"그런 거 아냐. 싱커는 그저 그런 버추얼 게임이 아냐. 물론 다른 게임들도 거의 진짜처럼 생생하긴 하지. 하지만 진짜가 아니잖아.”

"이 게임은 진짜라는 거야?"

"그래. 우리 건 진짜야. 뇌파 동조를 통해 직접 아마존을 체험하는 거지. 친구와 함께 할 수 있게

게임팩을 두 개 더 줄게.”(Bae, 2010, p. 23)

미마'는 게임을 통해서 실존하지 않는 생명체들을 보고, 듣고, 만지고, 조작하며 그것들이 실제로 존재한다고 믿는 사람들과 함께 사실은 아무것도 없는 공간 속을 모험한다. 가상현실 속 에서 우리는 이전에 한 번도 보지 못한 것 또한 '재인식'할 수 있다. 미마 역시 게임이라는 가상현실 속에서 동물이 고유하 게 갖고 있는 감각, 언어, 생리 등을 교감하는 능력을 획득하게 된다. 미마는 한 마리의 물고기와 도마뱀, 테이라 족제비, 재규 어가 이 공간에서 실제로 존재한다는 것을 느낀다. 싱크(sync) 즉 “어떤 진동체 고유의 진동수를 밖에서 오는 진동력의 진동 수에 일치시켜 공명시키는 일”(Bae, 2010, p. 37)을 통해서 동 물들이 느끼는 세상을 인간도 느낄 수 있게 된 것이다.

현실 세계에서 인간 고유의 지각과 표현, 행위의 전달 방법 은 도마뱀이 지니고 있는 지각과 표현, 행위의 전달 경로와 양 립하지 못한다. 그러나 미마는 가상현실을 통해서 인간의 감 각과 동물의 감각이 상호작용하는 새로운 리얼리티를 경험한 다. 미마는 게임을 이용하여 의사소통과 인식의 역량을 확대 한다. 동물의 세계를 미마와 친구들이 지각하게 되고 동물들 과 상호작용을 하게 되면서, 게임 속 동물들은 인간의 인식을 변형시키고, 자연에 대한 인간의 지식이나 정신적인 재현의 요소들 사이에도 상호작용이 일어난다. 다층적 감각을 통해 살아있는 동물들을 둘러싼 물질세계와 끊임없이 접촉하면서, 미마를 중심으로 한 게임유저들은 주체의 존재 양식 자체를 변화시킨다. 다른 개체들과의 싱크를 자유자재로 할 수 있게 되었을 때 미마는 "지성을 가진 자연의 한 세포로 화한 것처럼 느껴졌다. 그때 수업에서 그랬듯이 칸은 자연과 함께하는 다 른 방법을 체험하게 해주고 있었다.”(Bae, 2010, pp. 95-96)라고 느낀다.

그러나 이는 단순히 생태주의적 메시지를 전하는 것이 아 니다. 기존의 아동문학에서 환상 양식을 통한 생태적 생명력 의 가치는 중요하게 형상화되어 왔다. 채인선의 산골집에 도
깨비가 와글와글, 위기철의 쿨쿨 할아버지 잠 깬 날, 황선미의 마당을 나온 암탉 등의 작품들은 생명사상을 뛰어나게 표현 한 작품들이다. 그러나 이들 작품에서 자연은 인간에 의해 보 호되어야 할 '대상'일 뿐, 인간과 교감하는 동등한 '주체'로 설 정되지 못한다. 배미주는 이러한 동화의 계보를 계승하면서, 동시에 자연을 타자화하는 경향을 넘어서서 인간의 존재 양식 자체를 변화시키는 힘으로서의 자연을 형상화한다. 그리고 이 과정에서 환상은 인간과 인간, 나아가 인간과 동물의 관계를 재구성하는 힘으로 기능한다.

배미주의 작품에서 가상현실이 불러일으킨 정신적인 재인 식은 일시적인 도피에 그치는 것이 아니라 구체적인 현실로 귀환한다는 점에서 중요하다. '싱커'를 즐기는 유저들은 가상 의 공동체를 구성한다. 각 개인이 육체적으로 그곳에 존재하 지 않고도 다른 사람들과 함께 있을 수 있다는 점에서 지리적 인 공간을 초월한 공동체이다. 가상현실에서 나와 다른 개체, 인간과 다른 종(種)과의 동조 체험은 오프라인(off-line)의 '싱 커댄스'라는 역동적인 춤으로 재현되는가 하면, 초국적 제약 회사 간부의 아들인 탕쯔칭 패거리들의 폭력에 대해 집단적 저항 행동으로 변주되기도 한다. '싱커'게임을 즐기는 유저들 이 지니는 교감 능력은 단순한 타인에 대한 감정적 동조를 넘 어서, 나와 타자, 나아가 인간을 넘어선 동물의 실재를 감각하 고 이 모든 리얼리티를 적극적으로 재구성하고 확장하는 힘이 된다.

'싱커'게임을 통한 아마존 체험은 가상현실을 넘어서, 미마 와 부건이 속한 현실인 '시안'의 세계를 구성하는 엄연한 실재 로 기능한다. '시안'은 초국적 제약회사인 바이옥토퍼스에 의 해서 지배되는 도시이다. 초국적 자본주의의 지배 논리에 의 해서 바이러스의 매개체로 추방된 자연은 현실에서 추방된 가 상의 공간에서 재현된다. 게임 유저인 청소년들은 가상현실과 현실의 상호작용을 통해서 '시안'의 안과 바깥을 동시에 사유 할 수 있는 힘을 지니게 된다. 이러한 과정들을 통해서 가상현 실은 현실법칙과는 다른 실재를 복원시킨다.

가상현실과 현실이 자유롭게 상호작용하는 공간에서, '시 안을 벗어난 지상의 진짜 세계로 나아가서 생명력 넘치는 공 간으로 바꾸고자 하는 칸의 선택과 인공 세계인 '시안'의 현실 을 바꾸기 위해 도시에 남는 미마의 선택은 그 차이에도 불구 하고 똑같이 소중한 가치를 지닌다. 진짜 현실과 가상의 현실 은 진짜와 가짜 간의 위계질서에 의해서 가치의 우선 순위가 매겨지는 것이 아니다. 칸과 미마가 선택한 각기 다른 현실에 서 서로 다른 여러 겹의 리얼리티가 존재한다는 것을 서로 인 정하고, 함께 소통하는 것이 진정한 복수의 리얼리티를 인식 
하는 윤리이기 때문이다.

배미주가 싱커에서 확장한 가상현실은 단순한 기술 발달로 인한 것이 아니다. 이 작품은 개체사이의 연대와 교감을 가능 하게 하는 가상현실의 윤리적 측면까지 탐색하고 있기 때문에 새로우면서 중요하다. 개체들 간의 고립과 인간중심주의를 넘 어서 물질계 간의 경계를 동시에 극복할 수 있는 새로운 가상 현실의 문제가 청소년 문학을 통해 활짝 열려있다. 이는 한 편 으로는 확장된 과학기술에 직접적으로 영향을 받는 청소년들 의 삶을 반영한 것이며, 동시에 다른 한 편으로는 가상현실을 소재적이고 기술적인 층위에서 차용하는 것이 아니라 새로운 리얼리티의 문제로 고양시키는 것이기에 그 의미가 매우 크 다. 특히 더 이상 고전적인 리얼리티가 새로운 청소년 세대에 게 공감을 얻기 어려운 현실을 고려할 때, 배미주의 실험은 충 분히 주목될 필요가 있을 것이다.

\section{환상을 통한 새로운 청소년 문학의 모색}

2000년대 이후 청소년 문학은 청소년이 보다 넓은 세계와 대 면할 수 있는 새로운 미학을 치열하게 탐색하고 있음을 보여 준다. 주로 현실과 분리된 경이로운 세계로서 의미를 갖는 성 인 문학에서의 환상 개념과 달리, 청소년 문학에서의 환상은 객관현실을 반영하는 단일한 리얼리티를 넘어서 현실의 리얼 리티를 적극적으로 재구성하는 기능을 한다. 청소년 문학에서 의 환상은 리얼리티와 주체의 형성이라는 문제와 횔씬 단단하 게 결합되어 있다.

구병모, 최인석, 배미주의 작품들은 오늘날 새로운 리얼리 티를 탐색하는 환상의 힘을 보여준다. 하위문화에 기반한 마 술적 환상을 통해서 왜소화된 청소년이 기존 질서를 넘어서는 리얼리티를 구성하는 과정을 현대적으로 재해석하는 구병모, 금기의 경계를 넘는 사랑을 통해서 청소년의 욕망과 성장의 문법을 재구성하는 최인석, 가상현실을 통해서 복수(複數)의 리얼리티와 그 윤리를 모색하는 배미주 등은 모두 현실과 적 극적으로 상호작용하는 환상의 가능성을 탐구한다는 공통적 인 문제설정을 보여준다. 이들의 문학 작품에서 우리는 환상 을 매개로 재구성된 다양한 현실과 마주하게 된다.

교훈주의 문학, 계몽주의 문학, 사실주의 문학은 기존의 청 소년문학의 주류적 흐름을 이어왔다. 이들 문학은 청소년으로 하여금 질서, 규칙, 올바른 가치에 대한 정서적인 즐거움을 환 기해왔다. 그러나 성인 저자와 청소년 독자간의 비대칭성이라
는 독특한 의사소통 구조를 충분히 고려하지 못함으로써, 이 러한 경향의 문학은 직접적으로 청소년 독자를 억압하는 성인 작가의 권위적 목소리를 노출하거나 문학적 형식을 상투화하 는 한계를 보이고 있다. 특히 오늘날처럼 자아가 축소되어 수 동적이고 소박한 일상을 반복하고 있는 청소년들에게 이러한 경향은 더 이상 감동을 주지 못한다.

일상에서 가치가 충족되고 있지 않은 청소년들에게 현실의 규범을 넘어서거나 재구성할 수 있는 환상의 힘이 보다 절실 히 요청된다. 환상은 지배적 현실과 상호작용하면서, 청소년 의 현실과 위치를 보다 주체적으로 형상화할 수 있는 가능성 을 확대할 수 있다. 언제나, 청소년의 문법은 성인의 금지에 맞 서는 욕망을 추구하는 형식을 지니며, 이는 곧 다른 성장의 가 능성으로 나아가는 역동적인 힘을 지니기도 한다. 이를 뚜렷 하게 인식하는 청소년 문학이 환상과 결합될 때 우리 청소년 문학은 새로운 미학적 틀을 마련할 수 있을 것이다. 그리하여, 우리에게 여전히 환상은 현재진행형이다.

\section{Conflict of Interest}

No potential conflict of interest relevant to this article was reported.

\section{References}

\section{In English}

Wall, B. (1991). The Narrator's Voice: The Dilemma of Children's Fiction. London, UK: Palgrave Macmaillan.

\section{In Korean}

Bae, M. J. (2010). Syncher. Seoul: Changbi.

Choi, I. S. (2010). Robbery began. Seoul: Changbi.

Gu, B. M. (2009). Wizard bakery. Seoul: Changbi.

Jung, H. K. (2008). The deliemma of literature (for) the icon of this age, 'the youth'. Today's Literary Criticism, 71, 107-123.

Jung, H. K. (2009). Artificial paradise in closed ending. Changbi Children, 7(3), 41-52.

Ko, Y. G. (2009). For 'literature' for teenagers. Shilcheon Munhak, 95, 94-104.

Nikolajeva, M. (2009). Aesthetic approach of children's literature (H. S. Cho, Trans.). Seoul: Kyungmoonsa. (Original work 


\section{KJCS}

Hyun Sook Oh 270

published 2005)

Oh, S. R. (2009). Juvenile literature and not youth literature. Changbi Children, 24, 160-175.

Won, J. C. (2009). The development aspect of our youth literature. Shilcheon Munhak, 96, 213-226.

\section{ORCID}

Hyun Sook Oh http://orcid.org/0000-0001-6268-3124

Received February 3, 2017

Revision received February 13, 2017

Accepted February 21, 2017 